\title{
Process Form Responses of Shoreline Erosion Using Geo-Spatial Techniques: Case Study in Muriganga-Saptamukhi Interfluve, Sundarban
}

\author{
Abhishek Ghosh and Sutapa Mukhopadhyay \\ Department of Geography, Visva-Bharati, Santiniketan, West Bengal, India \\ Email:abhishekghosh20.3.90@gmail.com
}

\begin{abstract}
The numerous tidal river systems have made Sundarban delta one of the most dynamic geomorphic regions of the world. Through time morphological shape and extent of shoreline and river bank configurations have changed considerably through intense erosional and depositional processes by the longshore current and tidal flow pattern in Sundarban. The present study has made an assessment of morpho-dynamic behavior of bank lines for the time-period between 1925-26 and 2014 to identify nature and extent of erosion and deposition of different geomorphic units through consultation and preparation of geo-spatial database comprised of old maps and recent satellite images. Besides, detailed field investigations have also been carried out to understand different processes regarding the bank line changes. Finally different erosion hazard zones have been identified based on the net areal changes.
\end{abstract}

Keywords: Bank line changes, Erosion hazard zones, Hydro-geomorphic units, Net areal change, Sundarban

\section{Introduction}

The Earth's surface is continuously undergoing variety of physical and chemical changes. To understand the nature of these changes, their rates and relationship between form and process is the principal task of process-geomorphology. Coastal geomorphology is an emerging science with multidisciplinary approach mainly incorporates the study of coastal geomorphic environments, estuarine environment, their evolution, nature of neotectonic force acting on them, sediment dispersal, the processes at work on them and rate of changes now taking place. The coastal geomorphology comprised the study of different landforms in time and space. These landforms take their shape depending upon the ongoing coastal processes like erosional and depositional activities. Most of the coastlines owe their basic configuration to tectonic forces, coastal and estuarine hydrodynamic processes and geo-climatic hazards etc. It is noteworthy to mention that, nearly $75 \%$ of the world population resides along the coastal region. In this background proper understanding of coastal processes and changing coastal as well as estuarine landforms are necessary. In the last few decades, quantitative analyses on the bank line shift and shoreline configuration has been done by several scientists (Bandyopadhyay and Bandyopadhyay, 1996; Bandyopadhyay et al., 2004; Raju et al., 2010; Rahman, 2012; Chakraborty, 2013; Das et al., 2013). The present work endeavors to establish the dynamic nature of bank line configuration in estuarine belt of Sundarban to identify intensive erosion hazard zones in connection to ongoing processes using multi temporal database and geo-spatial techniques. This type of study can facilitate to build up structural and non-structural 
measurement strategies to overcome inconceivable land loss for geomorphologically chronicle areas like the Sundarbans.

\section{Geographical Appraisal of the Study Area}

The vast low lying flat deltaic tract of Sundarban has formed in the mouth of the Ganga Brahmaputra. The landform building processes are very active in this deltaic region. The central and northern part of the active deltaic tract of Sundarban has been affected by strong tidal force by tidally active rivers, at the same time the extreme southern part has been significantly affected by long shore current and strong wave dash activities of the Bay of Bengal (Bandyopadhyay and Bandyopadhyay, 1996; Paul, 2002; Das, 2006; Mikhailov and Dotsenko, 2007; Bandyopadhyay, 2007; Purkait, 2009; Chakraborty, 2013). The study area is situated in the western part of Sundarban in between Saptamukhi River in the east and Muriganga River in the west extending from $21^{\circ} 32^{\prime} 52^{\prime \prime}$ north to $22^{\circ} 0^{\prime} 40^{\prime \prime}$ north and $88^{\circ} 7^{\prime} 7^{\prime \prime}$ east to $88^{\circ} 22^{\prime} 28^{\prime \prime}$ east. Northern boundary has been demarcated based on Dampier-Hodges line which distinguished tidally active Sundarban delta from mature delta in north (Fig. 1). The region has experienced progressive land reclamation processes in last two centuries. At present population growth rate of this region is very fast. Thus, with the increasing population and land reclamation the natural landscape of Sundarban has been converted into human occupied territory (Mukherjee, 2002). The flat sandy coastal land is the main geomorphological characteristic in its southern tract. The central part of the study area is characterized by low lying flat topography with large number of interconnected tidal creeks and mostly lying at 2.8 to 4 meters elevation from mean sea level. Only the northern part is slightly elevated than the rest of the study area and the elevation from mean sea level is 3 to 6 meters on an average. This unique hydro-geomorphic setup makes marginal part of the study area very dynamic through the erosion and depositional processes (Chakraborty, 2013; Das et al., 2013).

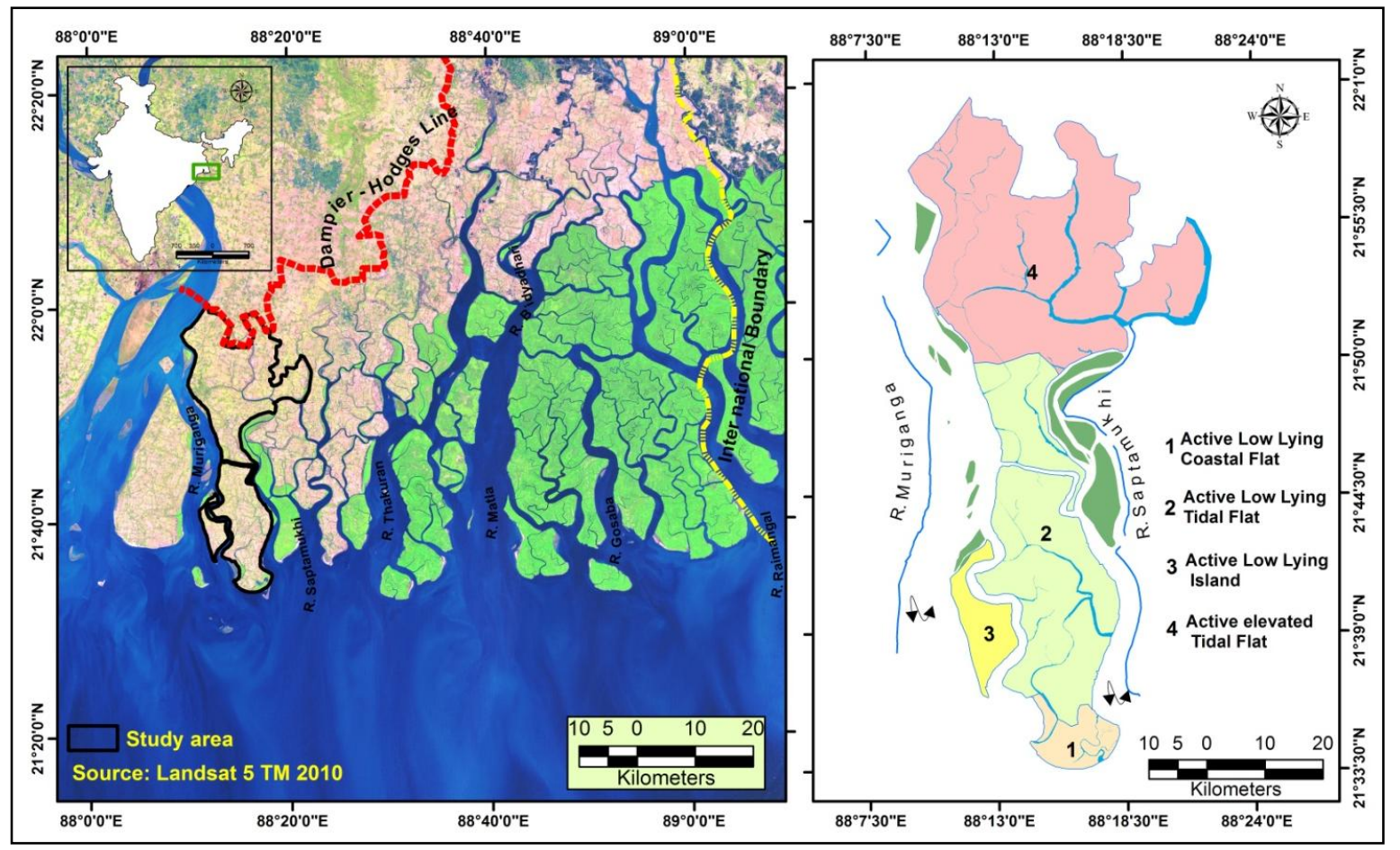

Fig.1: Geographical and geomorphological map of the study area. 
Open access e-Journal

Earth Science India, eISSN: $0974-8350$

Vol. 10 (I), January 2017, pp. 1- 12

http://www.earthscienceindia.info/

\section{Data Base and Methodology}

The concerned study focuses on the spatio-temporal changes of bank line shifting, extent of erosion and deposition along with erosion hazard zonation in western Sundarban using multi temporal maps and images (Table-1). The changing bank line configuration, extent of erosional and depositional patches have been extracted by imposing sequential digitized layers of successive periods (Bandyopadhyay and Bandyopadhyay, 1996; Bandyopadhyay et al., 2004; Raju et al., 2010; Mukhopadhyay et al., 2011; Rudra, 2012;Chakraborty, 2013; Das et al., 2013; Laha and Bandyopadhyay, 2013 Bandyopadhyay et al., 2014; Ghosh and Mukhopadhyay, 2016). After that, the net areal changes of different geomorphic units have been calculated from the total amount of erosion and deposition (between 1925-26 and 2014) to identify different erosion prone areas. Lastly to establish the adequacy of the present analysis repeated field checks were undertaken.

Table- 1: Materials used for the study.

\begin{tabular}{|c|c|c|c|c|c|}
\hline \multicolumn{2}{|c|}{ Maps } & \multicolumn{2}{|c|}{ Scale } & \multicolumn{2}{|c|}{ Time period } \\
\hline \multicolumn{2}{|c|}{$\begin{array}{l}\text { Police station maps of } \\
\text { Kakdwip and Namkhana } \\
\text { (Made and published under the } \\
\text { authority of settlement officer } \\
\text { Govt. of West Bengal) }\end{array}$} & \multicolumn{2}{|c|}{$1: 63,360$} & \multicolumn{2}{|c|}{$1925-26$} \\
\hline \multicolumn{2}{|c|}{$\begin{array}{l}\text { Survey of India Toposheets(79 } \\
\mathrm{c} / 1,79 \mathrm{c} / 2,79 \mathrm{c} / 5,79 \mathrm{c} / 6)\end{array}$} & \multicolumn{2}{|c|}{$1: 63,360$} & \multicolumn{2}{|c|}{1942} \\
\hline \multicolumn{2}{|c|}{$\begin{array}{l}\text { Survey of India Toposheets }(79 \\
\mathrm{c} / 1,79 \mathrm{c} / 2,79 \mathrm{c} / 5,79 \mathrm{c} / 6)\end{array}$} & \multicolumn{2}{|c|}{$1: 50,000$} & \multicolumn{2}{|c|}{$1967-68,1968-69$} \\
\hline \multicolumn{6}{|c|}{ Satellite image } \\
\hline Image & Date of Acquisition & Path & Row & $\begin{array}{l}\text { No. of } \\
\text { Bands }\end{array}$ & $\begin{array}{c}\text { Spatial } \\
\text { Resolution }\end{array}$ \\
\hline $\begin{array}{l}\text { IRS P6 } \\
\text { LISS IV }\end{array}$ & $18 / 02 / 2014$ & 108 & 57 & 3 & 5.8 metres \\
\hline
\end{tabular}

\section{Hydro-Geomorphic Setup of the Study Area}

The whole region can be sub-divided into four geomorphic units based on their diverse morphological setup, major processes and active operating agents (Table -2; Fig.1).

\section{Spatio-temporal Extent of Erosion and Depositional Activities}

The entire Sundarban deltaic region is strongly affected by tidal action. The region has two separate entities, the coastal tracts in the extreme southern part of the present study area has been influenced by long shore current, surges and seasonal wind action. The powerful wave generated during the monsoon season intensely affects the coastal dunes, and marginal sea facing embankments. On the other hand, the central and northern parts of the study region have been affected by tidally active rivers. Tidal flow strikes the exposed marginal land and earthen embankment with intense force and makes tremendous damages. The changing morphological 
configuration of the marginal parts clearly depicts erosional processes are active along the outer exposed reaches of the estuary and depositional processes are active along the interior and upper reaches of the estuary over time (Fig. 2).

Table-2: Geomorphic divisions of the study area.

\begin{tabular}{|l|l|l|l|l|}
\hline Geomorphic units & Relief & Drainage & Active processes & $\begin{array}{l}\text { Active geomorphic } \\
\text { agents }\end{array}$ \\
\hline $\begin{array}{l}\text { Active low lying } \\
\text { coastal flat }\end{array}$ & $\begin{array}{l}\text { 2-2.6 mts. } \\
\text { Flat and gentle } \\
\text { sloping towards } \\
\text { south }\end{array}$ & $\begin{array}{l}\text { Tidal } \\
\text { creeks } \\
\text { connected } \\
\text { with sea }\end{array}$ & $\begin{array}{l}\text { Erosion, deposition, } \\
\text { shore line changes, } \\
\text { Sand dune formation, } \\
\text { sands ply, salt marsh } \\
\text { formation }\end{array}$ & $\begin{array}{l}\text { Tide, wave, } \\
\text { long shore current, } \\
\text { seasonal wind } \\
\text { action }\end{array}$ \\
\hline $\begin{array}{l}\text { Active low lying } \\
\text { tidal flat }\end{array}$ & $\begin{array}{l}\text { 2.6-3.8 mts. } \\
\text { Flat and gentle } \\
\text { Sloping towards } \\
\text { marginal parts } \\
\text { from inner part }\end{array}$ & $\begin{array}{l}\text { Tidally } \\
\text { active rivers } \\
\text { and small } \\
\text { creeks with } \\
\text { dynamic } \\
\text { bank line }\end{array}$ & $\begin{array}{l}\text { Erosion, deposition, } \\
\text { bank line changes, } \\
\text { flood and prolonged } \\
\text { water stagnation }\end{array}$ & $\begin{array}{l}\text { Tidal action } \\
\text { and surges }\end{array}$ \\
\hline $\begin{array}{l}\text { Active low lying } \\
\text { island }\end{array}$ & $\begin{array}{l}\text { 3.9-2 mts. } \\
\text { Flat and gentle } \\
\text { sloping } \\
\text { towards south }\end{array}$ & $\begin{array}{l}\text { Surrounded } \\
\text { by large } \\
\text { rivers and } \\
\text { creeks }\end{array}$ & $\begin{array}{l}\text { Erosion, deposition of } \\
\text { Bank line, shifting } \\
\text { sand dune, sands ply, } \\
\text { salt marsh formation }\end{array}$ & $\begin{array}{l}\text { Tide, wave, surge, } \\
\text { seasonal wind } \\
\text { action }\end{array}$ \\
\hline $\begin{array}{l}\text { Active elevated } \\
\text { Tidal flat }\end{array}$ & $\begin{array}{l}\text { 3-6 mts. } \\
\text { Slightly elevated } \\
\text { and gentle } \\
\text { sloping } \\
\text { towards south }\end{array}$ & $\begin{array}{l}\text { Moderately } \\
\text { Stable small } \\
\text { tidal creeks }\end{array}$ & $\begin{array}{l}\text { Erosion, deposition, } \\
\text { bank line changes }\end{array}$ & $\begin{array}{l}\text { Tidal action } \\
\text { and surges }\end{array}$ \\
\hline
\end{tabular}

Source: SOI Toposheets1967 68, 1968 69, IRS P6 LISS IV Image 2014 and field investigation

In the lower and middle reaches of Muriganga estuary, the exposed concave left bank is severely affected by river bank erosional processes. On the other side, the exposed concave right bank of the lower and upper reaches of Saptamukhi river has been intensely affected by tidal thrust whereas large scale deposition took place along the concave right bank of the river Saptamukhi in the middle reaches of the estuary. The meandering outer concave bank line of Pits Creeks, Hatania-Doania creek is frequently affected by erosional processes whereas along the inner bank successive deposition took place (Fig. 3). Through time erosional processes overtake the depositional processes and the gap between erosion and deposition has increased significantly, thus enhancing the net regressive changes.

\section{Different Processes of Erosion}

Geomorphic extent of the Sundarban has changed successively over time depending on the intensity of erosion and depositional processes. The exposed marginal banks of the tidally active rivers have been severely affected by erosional processes, whereas sandy coastal beaches in the extreme southern parts of the study area have been severely blown up by the waves and long shore currents. The erosional processes are active in the exposed coastal belts and exposed concave river banks of the estuary, whereas the depositional processes are active in the inner 
Open access e-Journal

Earth Science India, eISSN: $0974-8350$

Vol. 10 (I), January 2017, pp. 1- 12

http://www.earthscienceindia.info/

sheltered reaches of the estuary. Different forms of bank erosion have been given in detail in the Table- 3.

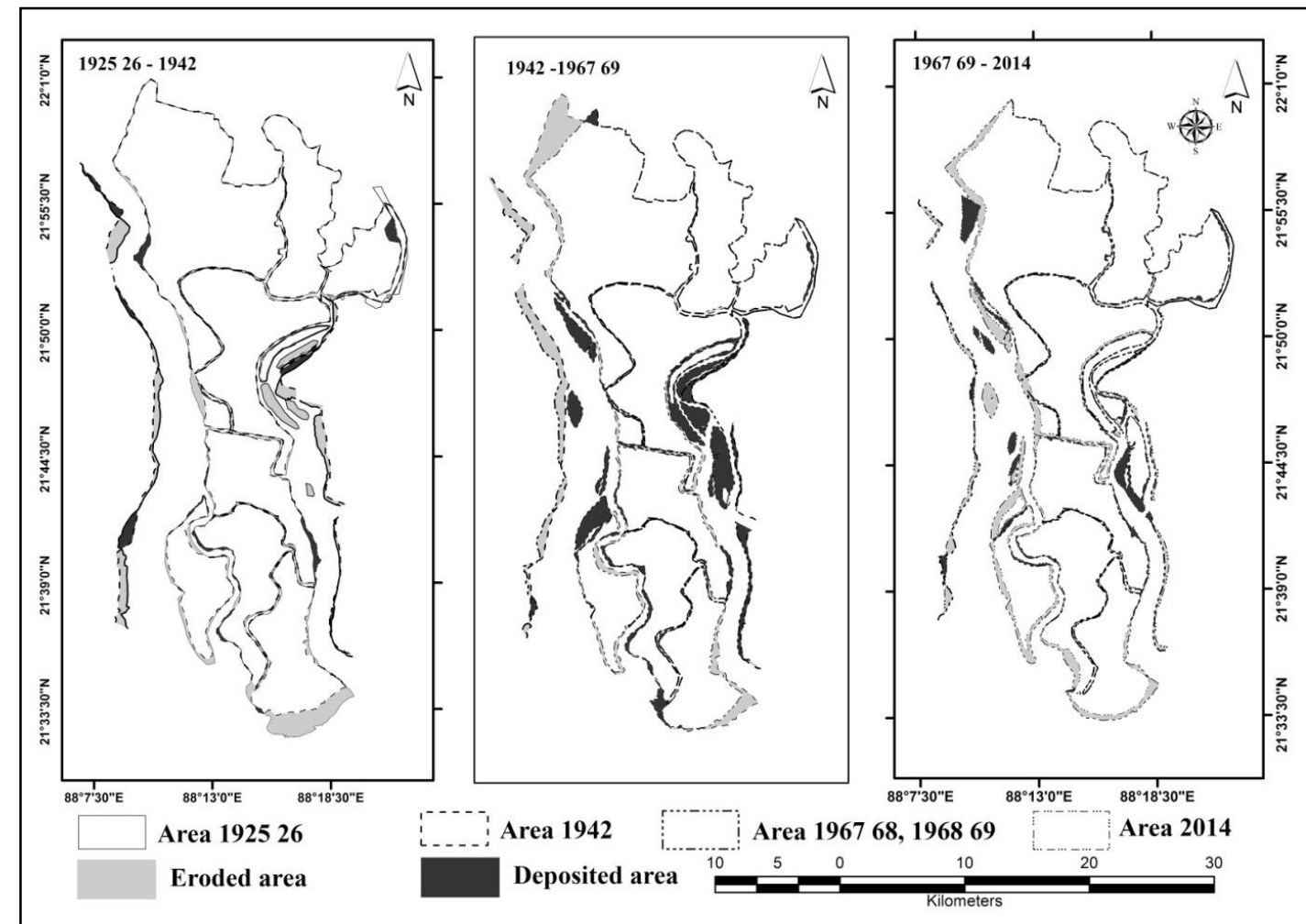

Fig. 2: Spatio-temporal extent of erosion and deposition.

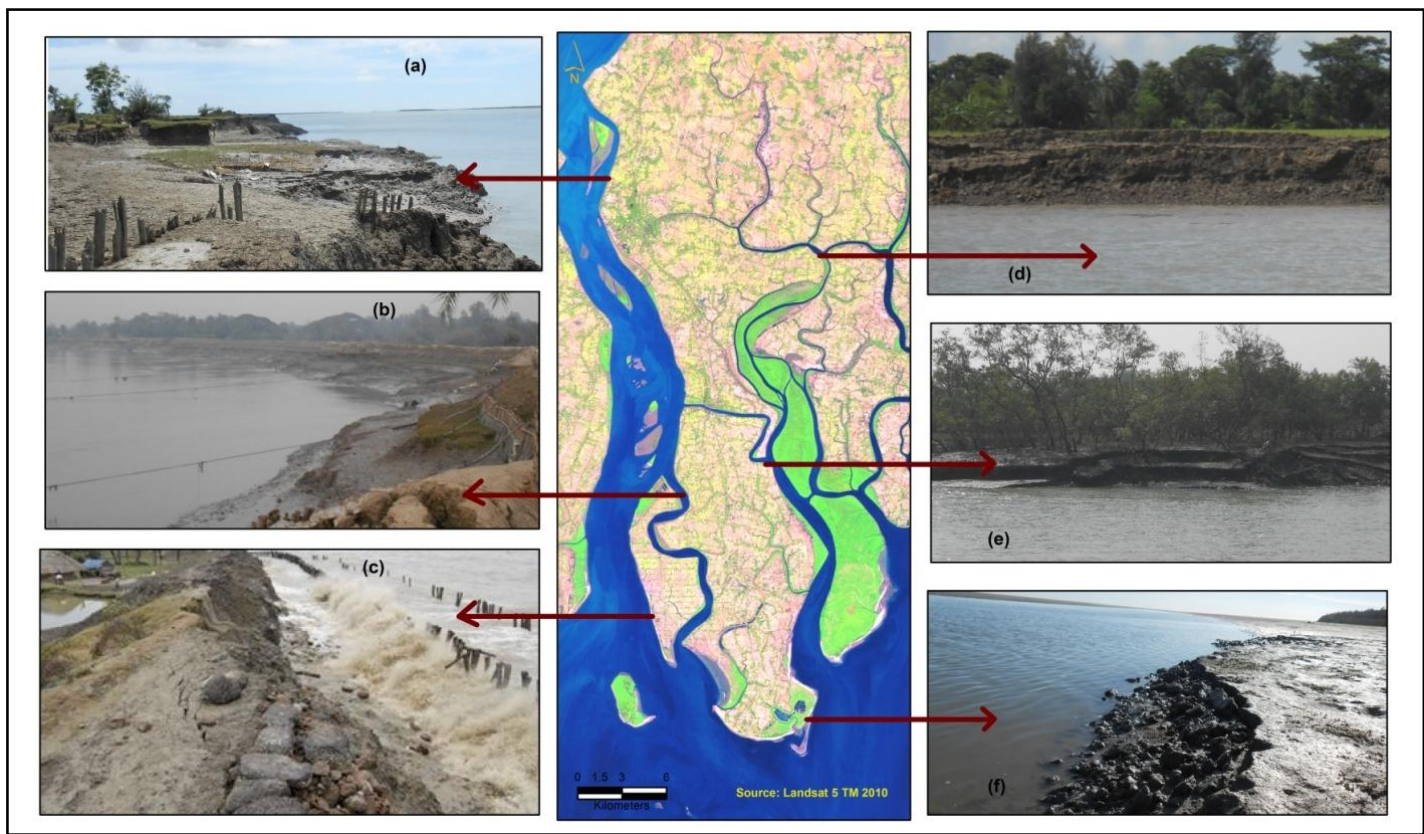

Fig. 3: Different forms of bank erosion (a, lateral erosion, b, under cutting, c, bank scouring, d, translational slide, e, slumping and $\mathrm{f}$, exposed mud sheet in different reaches of estuary). 
Table- 3: Different forms of bank erosion in the Muriganga Saptamukhi interfluve.

\begin{tabular}{|c|c|c|c|}
\hline \multicolumn{4}{|c|}{ Erosional processes } \\
\hline Process & Forms & Location & Probable factors and agents \\
\hline \multirow{8}{*}{$\begin{array}{l}\text { Hydraulic } \\
\text { action } \\
\text { Abrasion } \\
\text { Attrition }\end{array}$} & Bank scouring & $\begin{array}{c}\text { Mouth reach of Muriganga river (left } \\
\text { bank of Masuni island) }\end{array}$ & $\begin{array}{l}\text { Tidal action, wave dash, } \\
\text { exposure, Steep bank slope }\end{array}$ \\
\hline & $\begin{array}{l}\text { Under cut and } \\
\text { subsidence }\end{array}$ & $\begin{array}{l}\text { Meandering concave banks of Pits creek } \\
\text { and Hatania-Doania creek in the middle } \\
\text { reach of the estuary }\end{array}$ & $\begin{array}{c}\text { Tidal flow direction, channel } \\
\text { pattern, Very steep bank slope, } \\
\text { sinuous channel pattern, bank } \\
\text { composition }\end{array}$ \\
\hline & Lateral slide & $\begin{array}{l}\text { Middle and upper reaches of Muriganga } \\
\text { river }\end{array}$ & $\begin{array}{l}\text { Tidal flow velocity, Steep bank } \\
\text { slope, bank composition }\end{array}$ \\
\hline & $\begin{array}{l}\text { Slumping and } \\
\text { Rotational } \\
\text { slide }\end{array}$ & $\begin{array}{c}\text { Upper reach of Saptamukhi river, } \\
\text { middle and eastern part of Hatania- } \\
\text { Doania creek in the middle reach of the } \\
\text { estuary }\end{array}$ & $\begin{array}{l}\text { Tidal flow velocity, Steep bank } \\
\text { slope, sinuous channel pattern, } \\
\text { bank composition }\end{array}$ \\
\hline & $\begin{array}{l}\text { Translational } \\
\text { slide }\end{array}$ & $\begin{array}{l}\text { Lower and upper reach of Saptamukhi } \\
\text { river, eastern part of Hatania-Doania } \\
\text { creek near the junction with Saptamukhi } \\
\text { river in the middle reach of the estuary }\end{array}$ & $\begin{array}{l}\text { Tidal flow velocity, Steep bank } \\
\text { slope, bank composition }\end{array}$ \\
\hline & $\begin{array}{l}\text { Exposed dune } \\
\text { and mud sheet }\end{array}$ & $\begin{array}{l}\text { Fedric island, Henry's island } \\
\text { Along coastal tracts in extreme south }\end{array}$ & $\begin{array}{l}\text { Exposure, wave action, } \\
\text { cyclonic tidal rush, soil texture }\end{array}$ \\
\hline & Scoured rill & $\begin{array}{l}\text { Coastal belt along the Henry's island in } \\
\text { extreme south }\end{array}$ & $\begin{array}{l}\text { Exposure, wave action, } \\
\text { cyclonic tidal rush soil texture }\end{array}$ \\
\hline & $\begin{array}{l}\text { Erosive mud } \\
\quad \text { balls }\end{array}$ & $\begin{array}{c}\text { Low lying coastal belt along the } \\
\text { Henry's island }\end{array}$ & $\begin{array}{l}\text { Exposure, wave action, } \\
\text { cyclone, tidal rush, soil texture }\end{array}$ \\
\hline
\end{tabular}

Source: Based on field survey $2013-2016$

\section{Favourable Factors of Erosion}

Geotectonic setup: Due to the tectonic setup the Bengal basin has been tilted towards east. For this reason the Ganga River has changed its course from the historical past. Now the river use to flow in eastward direction. Due to the shifting course of the river Ganga most of the rivers of the Sundarban region in the western part of the Bengal basin has go through the paucity of fresh water discharge and sedimentation (Bandyopadhyay, 2007). The southern part of the delta is composed with loosely attached Holocene sedimentary strata and subjected gradual subsidence by the auto-compaction processes. The auto-compaction and gradual land subsidence have increased the relative sea level in the estuarine Sundarban region (Nandy and Bandyopadhyay, 2011).

Estuarine exposure: Sundarban is an active low lying area most of the area lies in between 2 to 6 meters elevation. The behead shoreline with funnel shape river mouths sustain more damage because the water is driven into a confined area by advancing tide and storms. Hence 
Open access e-Journal

Earth Science India, eISSN: $0974-8350$

Vol. 10 (I), January 2017, pp. 1- 12

http://www.earthscienceindia.info/

strong tidal thrust makes the marginal part very susceptible to erosion. In the extreme southern parts the low lying sandy coastal belts and exposed islands are severely affected long shore current, tidal surges and cyclones (Paul, 2002: Hazra, et al., 2010).

Tidal flow pattern: The Sundarban is a macro-tidal estuary where tidal range varies from $3 \mathrm{~m}$ to $5 \mathrm{~m}$ and may rise up to $8 \mathrm{~m}$ during normal spring tide. The duration of flood tide is 2 to 3 hours and ebb tide is continued to flow for 8 to 9 hours in 12.4 hours tidal cycle in the Hugli estuary. Thus, the low tidal water cannot properly pass out of the estuary. The average velocity of the flood tide is about 2 to $3 \mathrm{~meter} / \mathrm{second}$ and ebb tide is $<1 \mathrm{~meter} / \mathrm{second}$. Thus, it is found that the out flow continues in the ebb channels when the tide has already begun to move up the flood channels (Paul, 2002; Nandy and Bandyopadhyay, 2011). Thus, the flood tide brings huge sediments towards the estuary and gradually deposited in the shallow river bed disrupting equilibrium condition. Hence to accomplish the equilibrium condition estuary tries to erode the marginal bank and reset the equilibrium.

Channel configuration: Detail observation of bathymetric characters shows that the tidal rivers are characterized with some deep and shallow channels. The high tidal water enters through the shallow water channel and ebb tidal flow passes through the low deep tidal channel. All the deeps narrow elongated channels regulate the activities of erosion and deposition within estuary. The hydrodynamic forces concentrate within these elongated narrow channels at the ebb tide to produce maximum erosion in the estuary banks (Paul, 2002). Distribution of thalweg line and pattern of channel has strong connection with the erosion and depositional extent. The exposed concave banks of Muriganga and Saptamukhi river in their upper- middle and lower reaches are intensely affected by erosional processes whereas the inner concave banks have experienced deposition.

Fluctuation of mean tidal height: The estuarine part of Sundarban is funnel shaped. Hence, land ward increasing pattern of mean tidal ranges is commonly observed in estuarine tracts of Sundarban. Along with this, rapid sedimentation and land subsidence in connection with sediment auto- compaction also triggered the tidal ranges. Landward increasing pattern of tidal level is commonly noticed in Hugli estuary (Bandyopadhyay and Nandi, 2011). The present study attempts to understand long term changes in the mean sea level conditions sourced from the Permanent service for mean sea level (PSMSL) available in revised local reference (RAL) format. The study has decisively used long term annual mean sea level data of two observatories namely; Gangra station (31.4 kilometer from sea) for the periods of 1974 to 2006 and Haldia (43.4 Kilometer from sea) station for the periods of 1971 to 2009. The result shows the gradual land word increasing trend of mean sea level. Near Gangra it is nearly 0.41 millimeter per year but near Haldia the rate of increase is about 1.33 millimeter per year. Hence the shape of the estuary, sedimentation rate, land subsidence rate are seems to be responsible factors for such trends. The southwest monsoonal season has maximum tidal intensity hence erosional processes are much more active during this season (Hazra et al., 2010).

Cyclonic activities: Sundarban act as a transitional zone between Bay of Bengal and land masses. The cyclone originated over Bay of Bengal moves towards northern direction and directly knocks in this region (Bandyopadhyay, 1997; Hazra, et al., 2010; Danda et al., 2011; Ghosh, 2012). Heavy downpour, strong wind, massive surge collectively massacred this low lying tidal deltaic flat land through havoc bank erosion and prolonged flooding. Most of cyclonic activities are observed during June to October produce rapid bank erosion and 
inundates the marginal low lands. Storm surge height often exceeds 3 meters during cyclones cause greater damage in the low-lying islands and coastal belts.

Alignment of embankment and human interruption: Embankment material, lay out plan of construction, width-height ratio are not been well maintained. The Irrigation and water ways department of Government of West Bengal has constructed brick-lined embankment in some selected areas to prevent the erosion. Though in some most eroding stretches of south western coastal part and outer part of low lying island area the high tidal surges and breaking waves often penetrate and remove the cemented layer from the outer section and consequently the entire structure gradually collapses. Tremendous human interferences in the form of vegetation removal from marginal embankment, open pasture on embankment, constructions of houses at the base of embankment, use of embankment for transport collectively put tremendous pressure on embankment (Indian Institute of Technology, Kharagpur, 2006).

\section{Extent of Erosion Hazard in Different Geomorphic Units}

It has already been mentioned that the area has publicized negative alteration of aerial units but the magnitudes of erosion vary significantly over space and time. In order to understand the extent of erosion hazard over different geomorphic units the net change of the concerned area has been formulated out from the superimposed layers of different periods (Table-4 and 5; Fig.4). Any negative changes in shoreline and river bank configuration in this context indicate regressive changes of the geomorphic units which resembles the dominancy of erosional processes over depositional processes (Jana et al., 2012; Das et al., 2013). Such an outcome illustrate that the active low lying coastal flat are most hazard prone areas due to degree of exposure, relief, geomorphic set up and strong tidal influences. The active low lying tidal flat in the central part of the estuary is less susceptible to erosion as compared to other regions. The erosional processes predominate along the left side of the study area whereas depositional processes are active along the right side of the region and as a result of which net regressive change is quite meager. Active elevated tidal flat in the upper most part of the estuarine interfluve is experiencing moderate hazard intensity because the western bank of the Muriganga river is very erosion prone due to tidal flow pattern, and bathymetric characteristic (Fig. 4; Table- 6).

Temporal assessment depicts $60 \%$ decline of land area in active low lying coastal flat, $21 \%$ decline in active low lying tidal flat, $33 \%$ reduction of active low lying island between 1925-26 to 1942. However, upper elevated tidal flat has gained 16\% land area over the same temporal scale. Between 1942 to 1967 - 69 active low lying coastal flat declined by up to 10\%, active low lying tidal flat increased by up to $3 \%$, active low lying island decreased nearly by $33 \%$ and elevated tidal flat decreased remarkably by up to $69 \%$ from the previous time frame. And, during 1967-69 to 2014 active low lying coastal flat declined by approximately $28 \%$, active low lying tidal flat has declined sharply by around $81 \%$, active low lying island decreased by nearly $33 \%$ and elevated tidal flat declined by almost $46 \%$. The temporal fluctuation of areal units can be explained through the dynamic geotectonic setup of the region, changing trend of cyclonic frequencies, fluctuation of mean tide level, shifting of river thalweg lines, changing channel bed configuration, dynamics flow pattern and nature of human interruptions. 
Open access e-Journal

Earth Science India, eISSN: $0974-8350$

Vol. 10 (I), January 2017, pp. 1- 12

http://www.earthscienceindia.info/

Table- 4: Area under erosion and deposition (in sq.km.) in different geomorphic units.

\begin{tabular}{|c|c|c|c|c|c|c|c|c|}
\hline $\begin{array}{c}\text { Time/Area } \\
\text { (sq.km.) }\end{array}$ & \multicolumn{2}{|c|}{$\begin{array}{c}\text { Active Low Lying } \\
\text { Coastal Flat }\end{array}$} & \multicolumn{2}{c|}{$\begin{array}{c}\text { Active Low Lying } \\
\text { Tidal Flat }\end{array}$} & \multicolumn{2}{c|}{$\begin{array}{c}\text { Active Low Lying } \\
\text { Island }\end{array}$} & \multicolumn{2}{c|}{$\begin{array}{c}\text { Active elevated } \\
\text { Tidal Flat }\end{array}$} \\
\cline { 2 - 9 } & Erosion & Deposition & Erosion & Deposition & Erosion & Deposition & $\begin{array}{c}\text { Erosion } \\
\text { Depositio } \\
\text { n }\end{array}$ \\
\hline $\begin{array}{c}\mathbf{1 9 2 5 ~ 2 6}- \\
\mathbf{1 9 4 2}\end{array}$ & 11.68 & 0.5 & 6.4 & 4.3 & 4 & 0.6 & 4.4 & 7.9 \\
\hline $\begin{array}{c}\mathbf{1 9 4 2}-1967 \\
\mathbf{6 8 , 1 9 6 8 ~ 6 9}\end{array}$ & 4 & 2 & 5.8 & 5.9 & 5.1 & 1 & 9.9 & 1.6 \\
\hline $\begin{array}{c}\mathbf{1 9 6 7 ~ 6 8 ,} \\
\mathbf{1 9 6 8 ~ 6 9 -} \\
\mathbf{2 0 1 4}\end{array}$ & 5.5 & 0.1 & 7 & 2.9 & 5 & 0.5 & 6.3 & 2.4 \\
\hline
\end{tabular}

Source: Police station map of Kakdwip and Namkhana 1925-26, 1942, 1967 68, 196869 and IRS P6 LISS IV Image 2014

Table - 5: Spatial extent of erosion and deposition over time.

\begin{tabular}{|c|c|c|c|c|c|c|}
\hline \multirow{2}{*}{$\begin{array}{l}\text { Geomorphic } \\
\text { units }\end{array}$} & \multicolumn{2}{|c|}{ 1925-26 - 1942} & \multicolumn{2}{|c|}{$1942-1967-68,1968-69$} & \multicolumn{2}{|c|}{$1967-68,1968-69-2014$} \\
\hline & Erosion & Deposition & Erosion & Deposition & Erosion & Deposition \\
\hline $\begin{array}{c}\text { Active low } \\
\text { lying coastal } \\
\text { flat }\end{array}$ & $\begin{array}{c}\text { Entire } \\
\text { southern } \\
\text { part }\end{array}$ & $\begin{array}{c}\text { Patches in } \\
\text { eastern and } \\
\text { western parts }\end{array}$ & $\begin{array}{c}\text { Southern } \\
\text { and eastern } \\
\text { parts }\end{array}$ & $\begin{array}{c}\text { Mainly along } \\
\text { western part }\end{array}$ & $\begin{array}{c}\text { Almost } \\
\text { entire } \\
\text { shoreline }\end{array}$ & $\begin{array}{l}\text { Some isolated } \\
\text { patches in } \\
\text { western parts and } \\
\text { eastern parts }\end{array}$ \\
\hline $\begin{array}{l}\text { Active low } \\
\text { lying island }\end{array}$ & $\begin{array}{c}\text { Entire } \\
\text { southern } \\
\text { part }\end{array}$ & $\begin{array}{l}\text { Some patches } \\
\text { in north } \\
\text { western parts }\end{array}$ & $\begin{array}{c}\text { Entire } \\
\text { southern } \\
\text { part }\end{array}$ & $\begin{array}{l}\text { Some patches } \\
\text { in north } \\
\text { western parts }\end{array}$ & $\begin{array}{c}\text { Entire } \\
\text { southern } \\
\text { part }\end{array}$ & $\begin{array}{l}\text { Some patches in } \\
\text { north western and } \\
\text { north eastern } \\
\text { parts }\end{array}$ \\
\hline $\begin{array}{l}\text { Active low } \\
\text { lying tidal } \\
\text { flat }\end{array}$ & $\begin{array}{l}\text { North east, } \\
\text { north west } \\
\text { and south } \\
\text { east }\end{array}$ & $\begin{array}{l}\text { South western } \\
\text { part and } \\
\text { central part }\end{array}$ & $\begin{array}{l}\text { North east, } \\
\text { north west } \\
\text { and south } \\
\text { east }\end{array}$ & $\begin{array}{l}\text { South western } \\
\text { part, eastern } \\
\text { part and } \\
\text { central part }\end{array}$ & $\begin{array}{c}\text { North east, } \\
\text { north west } \\
\text { and south } \\
\text { east }\end{array}$ & $\begin{array}{l}\text { South western } \\
\text { part, eastern part } \\
\text { and central part }\end{array}$ \\
\hline $\begin{array}{c}\text { Active } \\
\text { elevated tidal } \\
\text { flat }\end{array}$ & $\begin{array}{c}\text { South } \\
\text { western part }\end{array}$ & $\begin{array}{c}\text { North western } \\
\text { parts }\end{array}$ & $\begin{array}{c}\text { Almost } \\
\text { entire } \\
\text { western part }\end{array}$ & $\begin{array}{l}\text { Some patches } \\
\text { in south } \\
\text { western part }\end{array}$ & $\begin{array}{l}\text { Almost } \\
\text { entire } \\
\text { western } \\
\text { part }\end{array}$ & $\begin{array}{c}\text { Some patches in } \\
\text { south western } \\
\text { parts }\end{array}$ \\
\hline
\end{tabular}

Source: Police station map of Kakdwip and Namkhana 1925 26, 1942, 1967 68, 196869 and IRS P6 LISS IV Image 2014 
Process Form Responses of Shoreline Erosion Using Geo-Spatial Techniques: Case Study in Muriganga-Saptamukhi Interfluve, Sundarban: Ghosh and Mukhopadhyay

Table- 6: Net changes (sq.km.) of the interfluve area 192526 -2014.

\begin{tabular}{|c|c|c|c|}
\hline Time /Area in sq.km. & $\begin{array}{c}\text { Eroded area } \\
\text { (sq.km.) }\end{array}$ & $\begin{array}{c}\text { Deposited area } \\
\text { (sq.km.) }\end{array}$ & $\begin{array}{c}\text { Net change } \\
\text { (sq.km.) }\end{array}$ \\
\hline $\begin{array}{c}\text { Active low lying coastal } \\
\text { flat }\end{array}$ & 18.71 & 0.4 & -18.31 \\
\hline Active low lying tidal flat & 16.14 & 9.04 & -7.1 \\
\hline Active low lying island & 10.73 & 0.9 & -9.83 \\
\hline Active elevated tidal flat & 19.66 & 10.33 & -9.33 \\
\hline
\end{tabular}

Source: Police station map of Kakdwip and Namkhana 1925-26, 1942, 1967 68, 196869 and IRS P6 LISS IV Image 2014

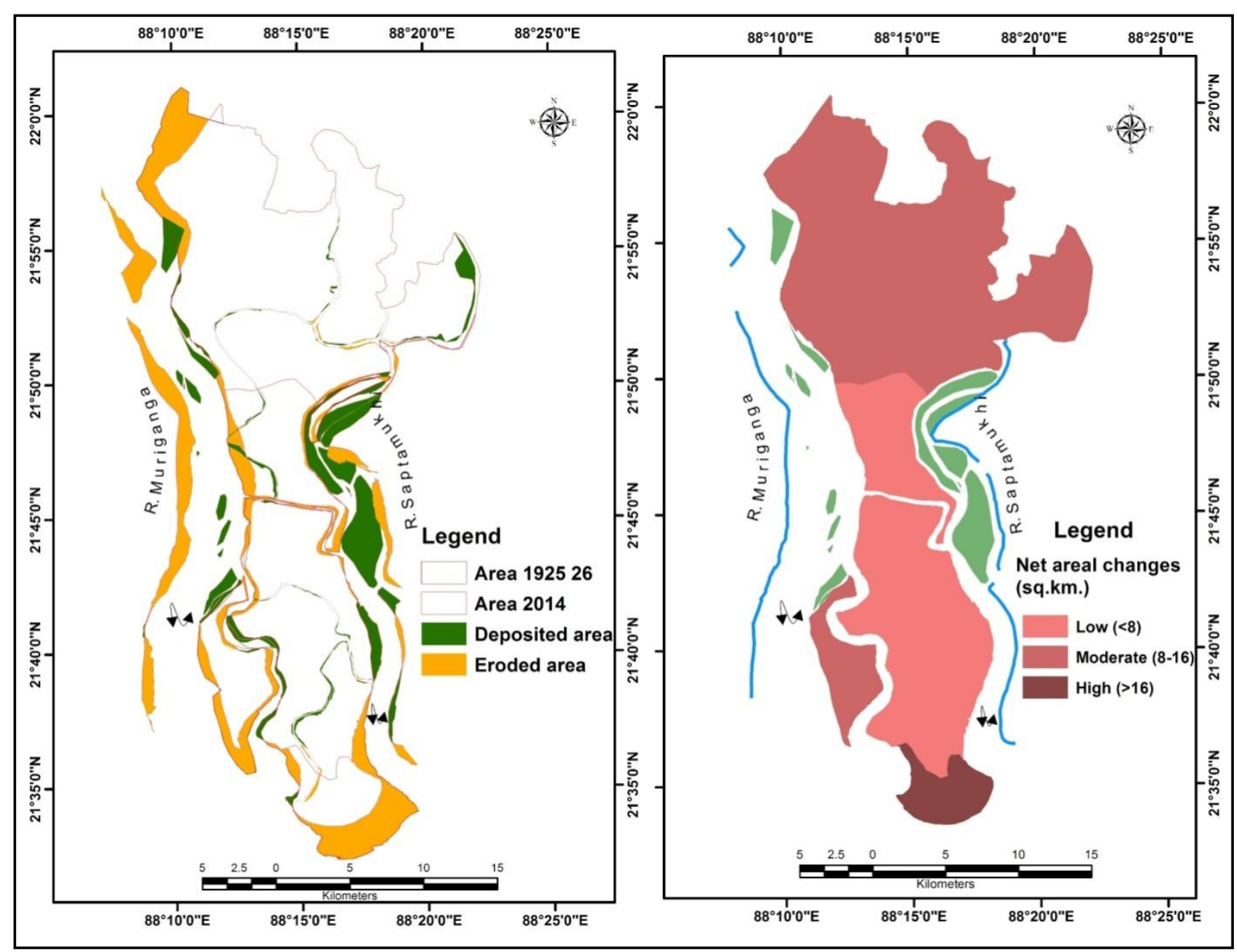

Fig. 4: Spatio temporal extent of erosion and deposition in different geomorphic units (1925 26 to 2014) (Left) and extent of erosion hazard in different geomorphic units (1925 - 26 to 2014) (Right) 
Open access e-Journal

Earth Science India, eISSN: $0974-8350$

Vol. 10 (I), January 2017, pp. 1 - 12

http://www.earthscienceindia.info/

\section{Concluding Remarks}

Shoreline and the river banks are dynamically related over time and space. The erosional processes are active in the exposed outer reaches of the estuary whereas depositional processes are active in inner, protected sheltered reaches. Over time, amount of erosion overtakes deposition as a result total area is in decreasing state. Further, micro-level analysis depicts the outer coastal belt is most erosion prone followed by the exposed low lying island. On the other hand, erosion hazard intensity is quite less in upper and middle reaches of the estuary. Changes in bank line configuration are directly related with tidal flow velocity, flow direction, channel pattern, bathymetric condition of channel, composition of river banks and locational extent of chars.

Through time the area is experiencing regressive changes over time but amount of net areal change vary significantly between different geomorphic units which may have a negative impact on dwellers. So proper knowledge development about the ongoing processes, intense monitoring of the changing behavior of existing processes, structural and non-structural planning and management and integration between local demands and planning bodies are utmost necessary to overcome the challenges like heavy erosion, unscientific land encroachment for the betterment of Sundarban and its dwellers in near future.

Essence of this work lies in the fact that it explores the spatio-temporal extent of bank line alteration, probable factors of bank line changes, spatial extent of bank erosion hazard in a quantitative manner using multi-temporal maps and images. Moreover, this type of study can be carried out for the entire Sundarban region, which would be useful for the creation of more comprehensive coastal erosion hazard risk maps and a better spatial measurement of the risks associated with such natural hazard.

\section{References}

Bandyopadhyay, J., Mondal, I. and Samanta, N. (2014) Shore Line shifting of Namkhana island of Indian Sundarban, South 24 Parganas, West Bengal, India, Using Remote Sensing \& GIS Techniques. International journal of Engineering Sciences \& Research Technology, v. 3(5), pp. 162-169.

Bandyopadhyay, S. (1997) Natural environmental hazard and their management case study of Sagar island India. Singapore Jour. Tropical Geography, v. 18, pp. 20-25. doi: 10.1111/1467-9493.00003.

Bandyopadhyay, S. (2007) Evolution of the Ganga-Brahmaputra Delta: A Review. Geographical review of India, v. 69 (3), pp. 235-268.

Bandyopadhyay, S. and Bandyopadhyay, M.K. (1996) Restrogradation of the Western Ganga-Brahmaputra Delta (India and Bangladesh): Possible reasons. National Geographer, v. 31 (Nos. 1 \& 2), pp. 105-128.

Bandyopadhyay, S. and Nandy, S. (2011) Trends of sea level rise in Hugli estuary, India. Indian Journal of Geomarine Sciences., v. 40, pp. 802-812.

Bandyopadhyay, S., Mukherjee, D., Bag, S., Pal, D.K. and Rudra, K. (2004) $20^{\text {th }}$ Century evolution of banks and islands of the Hugli Estuary, West Bengal, India: Evidence from Maps, Images and GPS Survey. In: S. Singh, H.S. Sharma, S.K. De (eds.) Geomorphology and Environment. ACB Publications, Kolkata, pp. 235-263.

Chakrabarti, P. (1995) Evolutionary history of the coastal quaternaries of the Bengal plain, India.proc. Indian Nat. Sci. Acad., v. 61, A, (No5), pp. 343-354.

Chakraborty, S. (2013) Delineation of morpho-structural changes of some selected islands in the Ganga delta region, West Bengal, India- a spatio-temporal change detection analysis using GIS and Remote sensing. International Journal of Science and Nature, v. 4(3), pp. 499-507. 
Danda, A., Anurag, A., Sriskanthan, G., Ghosh, A., Bandyopadhyay, J. and Hazra, S. (2011) Indian Sundarbans delta: a vision. World Wide Fund for Nature-India, New Delhi. 40 p.

Das, G.K. (2006) Sunderbans environment and ecosystem, Sarat Book Distributors, Kolkata. pp. 30-73.

Das, S., Choudhury, M.R., Das, S. and Khan, S. (2013) Monitoring shore line and inland changes by using MultiTemporal Satellite Data and risk assessment: A case study of Ghoramara Island, West Bengal. Int. J. Geos. \& Tech., v. 1 (1), pp. 1-20.

Ghosh, A. (2012) Living with changing climate Impact, vulnerability and adaptation challenges in Indian Sundarbans. In: J. Chaudhuri (ed.) Centre for Science and Environment, New Delhi. 91p.

Ghosh, A. and Mukhopadhyay, S. (2016) Quantitative study on shoreline changes and erosion hazard assessment: case study in Muriganga-Saptamukhi interfluve, Sundarban, India. Model Earth Syst. Environ., v. 2(2), pp. 1-14. doi: 10.1007/s40808-016-0130-x

Hazra, S., Samanta, K., Mukhopadhyay, A. and Akhand, A. (2010) Temporal change detection (2001-2008) study of Sundarban (Final Report). School of Oceanographic Studies, Jadavpur University, 127p.

Indian Institute of Technology, Kharagpur (2006) Hazard assessment and disaster mitigation for West Bengal due to tropical cyclones. Available from: http://www.iczmpwb.org/main/pdf/ebooks/Disaster\%20Management\%20Report_West\%20Bengal.pdf., Project report accessed on 28.08.2014.

Jana, A., Sheena, S. and Biswas, A. (2012) Morphological change study of Ghoramara island, Eastern India using Multi Temporal Satellite Data. Research Journal of Recent Sciences, v.1 (10), pp. 72-81.

Laha, C. and Bandyopadhyay, S. (2013) Analysis of the changing morphometry of River Ganga, shift monitoring and vulnerability analysis using Space-Borne Techniques: A statistical approach. International Journal of Scientific and Research Publications, v. 3, pp. 1-10.

Mikhailov, V.N. and Dotsenko, M.A. (2007) Processes of delta formation in the mouth area of the Ganges and Brahmaputra rivers. Hydrological Processes, v. 34(4), pp. 385-400. doi: 10.1134/S0097807807040033.

Mukherjee, K.N. (2002) Sundarban histogenesis, hazards and nemeses, changing environmental scenario of the Indian Sundarban. ACB Publication, Kolkata. pp. 263-280.

Mukhopadhyay, A., Mukherjee, S., Hazra, S. and Mitra, D. (2011) Sea level rise and shoreline changes: a geoinformatic appraisal of Chandipur coast, Orissa. International Journal of Geology, Earth and Environmental Sciences, v. 1(1), pp. 9-17.

Nandy, S., Bandyopadhyay, S. (2011): Trends of sea level rise in Hugli estuary, India. Indian journal of Geomarine Sciences, v. 40, pp. 802-812.

Paul, A.K. (2002) Coastal geomorphology and environment: Sundarban coastal plain, Kathi coastal plain, Subarnarekha delta plain. ACB Publications, Kolkata.pp. 131-559.

Purkait, B. (2009) Coastal erosion in response to wave dynamics operative in Sagar island, Sundarban delta, India. Front. Earth Sci. China, v. 3(1), pp. 21-33. doi: 10.1007/s11707-009-0001-0.

Rahman, M.M. (2012) Time-series analysis of coastal erosion in the Sundarbans mangrove. International Archives of the Photogrammetry, Remote Sensing and Spatial Information Sciences, v. 39(B8), pp. 425-429.

Raju, D.K., Santosh, K., Chandrasekar, j. and Tiong-Sa, T. (2010) Coastline change measurement and generating risk map for the coast using geographic information system. The International Archives of the Photogrammetry, Remote Sensing and Spatial Information Sciences., v. 38 (part II), pp. 492-497.

Rudra, K. (2012) The Atlas of the changing river courses in West Bengal.Sea Explorers' Institute (SEI), Kolkata.

(Received: 18.06.16; Accepted: 10.01.2017) 